Available online at website : http://journal.uinjkt.ac.id/index.php/dialektika

DIALEKTIKA: jurnal bahasa, sastra, dan pendidikan bahasa dan sastra Indonesia, 3(1), 2016, 20-35

\title{
OBSESI TOKOH UTAMA TERHADAP MAKANAN DALAM NOVEL ARUNA DAN LIDAHNYAKARYA LAKSMI PAMUNTJAK
}

\author{
Noviana Nitami \\ Sekolah Dasar Islam Terpadu (SDIT) Al-Muqorrobin, Indonesia \\ E-mail: noviananitami28@gmail.com
}

\begin{abstract}
This study is motivated by the human changes in treating food which is caused by the displacement of society, technology, culture and time change. The aims of this study is to find the obsession on the food in the novel Aruna dan Lidahnya. The method used in this research is descriptive qualitative, in which data is collected by library research. The research result in the leading factor of the main character's obsession to the food, single status, source of happiness, a mean of self-liberation, occupational factors, lifestyle, and educational background. Aruna's obsession is categorized as compulsive obsession. Compulsive obsession is a repetitive behaviour that performed by someone because she thinks it ia a must.
\end{abstract}

Keywords: Aruna dan Lidahnya; Laksmi Pamuntjak; Food; Obsession; Literature learning

\begin{abstract}
Abstrak: Penelitian ini dilatarbelakangi oleh perubahan manusia dalam memperlakukan makanan yang disebabkan oleh adanya perpindahan masyarakat, budaya teknologi, dan perkembangan zaman. Tujuan dari penelitian ini untuk mengetahui obsesi terhadap makanan yang terdapat dalam novel Aruna dan Lidahnya. Metode yang digunakan ialah deskriptif kualitatif. Teknik pengumpulan data dilakukan dengan teknik kajian pustaka. Teknik analisis data dilakukan dengan analisis struktural yakni membaca dan memahami kembali data yang sudah diperoleh. Berdasarkan penelitian, diperoleh hasil bahwa obsesi terhadap makanan yang terdapat dalam novel Aruna dan Lidahnya karya Laksmi Pamuntjak disebabkan oleh beberapa faktor, di antaranya faktor status yang masih sendiri, sumber kebahagiaan, sarana pembebasan diri, faktor pekerjaan, gaya hidup, dan latar belakang pendidikan. Obsesi yang dialami oleh Aruna tergolong ke dalam obsesi kompulsif yaitu perilaku yang dilakukan berulang-ulang oleh seseorang karena merasa harus melakukannya.
\end{abstract}

Kata Kunci: Aruna dan Lidahnya, Laksmi Pamuntjak, Makanan, Obsesi, Pembelajaran Sastra

Permalink/DOI: http://dx.doi.org/10.15408/dialektika.v3i1.4182 


\section{Pendahuluan}

Perkembangan kemajuan zaman menghasilkan perubahan dalam budaya makan pada masyarakat di seluruh dunia. Makanan turut mengalami proses adaptasi dari tradisional menjadi modern. Hal ini disebabkan karena adanya perpindahan masyarakat, budaya teknologi, dan sebagainya. Selain itu, makanan setiap daerah memiliki ciri khasnya masing-masing. Ciri khas tersebut biasanya berasal dari cita rasa serta bahan dasar yang digunakan. Begitu banyak jenis makanan dari seluruh dunia yang unik, sehingga makanan pun menjadi sebuah budaya dari masing-masing daerah atau suatu kebudayaan. Perkembangan makanan itu sendiri saat ini telah menjadi suatu budaya dan gaya hidup. Variasi makanan membuat orang di belahan dunia berbeda akan makan sesuatu yang berbeda pula dan membentuk karakter makanan serta cara makan yang berbeda. Dari situlah lahirnya makanan dan kegiatan makan sebagai budaya dan gaya hidup.' Perkembangan ilmu pengetahuan dan teknologi juga memengaruhi perlakuan manusia terhadap makanan. Hadirnya media sosial seperti Blog, Facebook, Twitter, Tumblr, Instagram, dan Path memberi pengaruh terhadap masyarakat dalam memperlakukan makanan. Peristiwa serta tingkah laku manusia yang acap kali ditemukan dan terjadi dalam kehidupan sehari-hari, ternyata tidak hanya berada dalam dunia nyata. Para sastrawan yang melihat fenomena ini sebagai hal yang menarik, menjadikannya peluang untuk menyampaikan buah pikiran mereka melalui kata dan karya.

Berdasarkan pemaparan di atas, penelitian ini akan berfokus pada novel Aruna dan Lidahnya karya Laksmi Pamuntjak (Jakarta: PT Gramedia Pustaka Utama, 2014). Adapun alasan yang memperkuat novel Aruna dan Lidahnya karya Laksmi Pamuntjak dijadikan sebagai objek penelitian dikarenakan masih minimnya penelitian yang membahas makanan sebagai objek kajiannya.

\section{Metode Penelitian}

Metode penelitian yang digunakan dalam penelitian ini ialah metode kualitatif. Penelitian kualitatif ialah pendekatan yang menggambarkan dan menganalisis setiap individu dalam kehidupan dan pemikirannya. Agar objek dan peristiwa yang diteliti dapat dipahami, maka cara yang tepat ialah dengan cara mendeskripsikan dan mengeksplorasikannya ke dalam sebuah narasi. Dalam

'Robin Redmon Wright, You are What You Eat!? Television Cooking Show, Consumotion, and Lifestyle Practices as Adult Learning, (San Antonio: New Prairie Press, 2009), h.404. 
novel Aruna dan Lidahnya karya Laksmi Pamuntjak menggunakan metode kualitatif deskriptif. Hasil yang didapatkan berbentuk deskripsi, tidak berupa angka-angka. Langkah pertama yang dilakukan dalam penelitian ini adalah menganalisis novel Aruna dan Lidahnya karya Laksmi Pamuntjak dengan menggunakan analisis struktural. Analisis struktural dilakukan dengan membaca dan memahami kembali data yang sudah diperoleh. Berikutnya mengelompokkan teks-teks yang terdapat dalam novel Aruna dan Lidahnya karya Laksmi Pamuntjak. Analisis selanjutnya dilakukan dengan membaca serta memahami kembali data yang diperoleh. Selanjutnya mengelompokkan teksteks yang berhubungan dengan dengan bahasan obsesi terhadap makanan yang terdapat dalam novel.

\section{Landasan Teori}

Pengertian Novel

Novel merupakan salah satu jenis karya sastra yang paling banyak dibaca oleh masyarakat pembaca dibandingkan dengan karya sastra yang lainnya, karena dalam karya sastra yang satu ini, pembaca dapat mengetahui lebih detail jalan cerita serta permasalahan yang terdapat dalam novel. Beberapa pandangan yang mengemukakan mengenai istilah novel sebagai berikut.

Kamus Istilah Sastra (2007:36) mendefinisikan novel sebagai jenis prosa yang mengandung unsur tokoh, alur, latar rekaan yang menggelarkan kehidupan manusia atas dasar sudut pandang pengarang dan; mengandung nilai hidup. ${ }^{2}$

Secara harfiah novella berarti sebuah barang baru yang kecil, dan kemudian diartikan sebagai 'cerita pendek dalam bentuk prosa'. Dewasa ini istilah novella dan novelle mengandung pengertian yang sama dengan istilah Indonesia novelet (Inggris : novellete), yang berarti sebuah karya prosa fiksi yang panjangnya cukup, tidak terlalu panjang, namun tidak juga terlalu pendek. ${ }^{3}$ Banyak para ahli yang memiliki definisi berbeda mengenai novel, namun semuanya hampir sama yakni novel merupakan cerita fiksi yang bersifat imajinatif dalam bentuk prosa panjang yang di dalamnya terdapat tokoh dengan segala perilaku dan permasalahannya yang diangkat dari refleksi kehidupan nyata.

\section{Obsesi}

Manusia merupakan makhluk sosial yang ditengarai tidak pernah puas dalam memenuhi kebutuhannya. Ketika sudah mendapatkan keinginan yang satu, maka

\footnotetext{
${ }^{2}$ Abdul Rozak Zaidan, Anita K.Rustapa dkk, Kamus Istilah Sastra, (Jakarta: Balai Pustaka, 2007), h.136.

${ }^{3}$ Burhan Nurgiantoro, Teori Pengkajian Fiksi, (Yogyakarta: Gajah Mada University Press, 2010), h. 9-10.
} 
keinginan lainnya bersiap untuk diwujudkan, dan begitu seterusnya. Sifat manusia yang tidak pernah puas ini terkadang memicu keinginan yang berlebihan dalam menggapai sesuatu. Hal seperti ini sering disebut sebagai obsesi.

Definisi obsesi dalam The Webster's Dictionary “ialah ide, pikiran, bayangan atau emosi yang tidak terkendali, sering datang tanpa dikehendaki atau mendesak masuk dalam pikiran seseorang yang mengakibatkan rasa tertekan dan cemas". ${ }^{4}$

Pengertian lain obsesi dikemukakan Kaplan dalam Anggraeni adalah pikiran, ide, atau sensasi yang muncul tanpa kendali. Davison dan Neale mengungkaplan bahwa hal-hal tersebut muncul tanpa dapat dicegah, dan individu merasakannya sebagai hal yang tidak rasional dan tidak dapat dikontrol. ${ }^{5}$ Obsesi yang terjadi atau dialami oleh manusia masih bisa dikatakan berada dalam batas wajar jika seseorang itu tidak berlebihan atau berulang-ulang memikirkan hal yang sama. Jika hal ini terjadi sampai berulang-ulang dan mengganggu fungsi keseharian serta disertai dengan kecenderungan melakukan sesuatu yang berulang untuk mengurangi kecemasan yang ditimbulkan akibat pikiran tersebut, Retha Arjadi mengatakan itu merupakan gangguan psikologis.

Pikiran yang terus menerus berulang hingga mengganggu keseharian termasuk ke dalam gangguan psikologis. Gangguan psikologis yang dimaksud dikenal dengan gangguan obsesif kompulsif. Gangguan ini ditandai oleh dua komponen yaitu obsesi dan kompulsi. Obsesi adalah pikiran-pikiran yang menetap, berulang, dan bersifat mengganggu hingga menimbulkan kecemasan dalam diri orang yang mengalaminya. Sementara itu, kompulsi adalah perilaku yang dilakukan berulang-ulang oleh seseorang karena merasa harus melakukannya. Orang tersebut meyakini bahwa dengan melakukan perilaku berulang tersebut, kecemasan yang ia alami terkait obsesi pikirannya dapat berkurang. ${ }^{6}$

\section{Makanan}

Makanan ialah kebutuhan utama bagi manusia, karena kegiatan ini bisa dikatakan sebagai penunjang keberlangsungan hidup manusia untuk beraktivitas seharihari. Jenis makanan yang ada pun saat ini sudah berbeda dari sebelumnya. Jika dahulu manusia hanya memakan makanan yang mentah, kemudian dibakar, direbus, dipanggang, dan pada akhirnya kini cara mengolah makanan tersebut sudah semakin bervariasi.

Indonesia, sebagai negara yang terdiri dari berbagai macam suku bangsa, tentu memiliki jenis makanan dan cara pengolahan yang berbeda-beda di setiap daerah. Selain

\footnotetext{
${ }^{4}$ Retha Arjadi, Melakukan Sesuatu Berulang, Waspadai Gangguan Obsesif-Kompulsif, (Jakarta: PT Kompas Media Nusantara, 2015), h.2.

${ }^{5}$ Mareta Anggraeni, Perilaku Obsesif Kompulsif Disorder pada Peserta Penurunan Berat Badan, (Skripsi Universitas Brawijaya Malang: Tidak diterbitkan, 2013).

${ }^{6}$ Retha Arjadi, Melakukan Sesuatu Berulang, Waspadai Gangguan ....., h.3.
} 
suku dan bangsa, masakan merupakan bukti kebinekaan Indonesia. Tidak ada negara yang memiliki ragam kuliner sekaya Indonesia. Keragaman itu memiliki akar sejarah panjang. Keadaan politik dan ekonomi suatu daerah sangat menentukan variasi makanan penduduk.

Setiap makanan yang ada di suatu daerah memiliki ciri khas tersendiri yang membedakannya dengan makanan di daerah lain. Makanan di Jawa misalnya dikenal dengan ciri khas manis, makanan di Minahasa yang terkenal pedas, sementara di Indonesia bagian Timur yang tidak mempergunakan terlalu banyak bumbu, di Sumatera yang berkebalikan dengan Indonesia Timur, di daerah tersebut bumbu yang dipergunakan bisa mencapai belasan hingga puluhan dalam sekali memasak.

William mengemukakan, makanan Indonesia saat ini seperti bahasa di Indonesia sebelum Sumpah Pemuda, beragam dan tidak dipersatukan oleh bahasa apa pun. Hanya, kita tidak perlu memperbarui Sumpah Pemuda dan memasukkan sumpah baru: "Memakan makanan yang satu, makanan Indonesia." Sebab, pada keberagamannya itulah kekuatan khazanah kuliner Indonesia. Tidak ada negara yang makanannya begitu beragam seperti Indonesia. ${ }^{8}$

Ritual makan bersama merupakan pengikat hubungan antar sesama. Oleh karena itu, banyak orang-orang yang menggunakan makanan sebagai media dalam memecahkan masalah salah satunya. Berwisata kuliner juga menjadi aktivitas yang digemari dewasa ini. Namun, hanya sedikit orang yang mengkonsusmsi makanan dengan mengetahui proses pembuatan di baliknya. Wisata kuliner bukan hanya menyantap makanan di warung. Wisata kuliner adalah pergi ke satu daerah, mendatangi kebun-kebun rimbun tempat bahan makanan ditanam, mengunjungi pasar untuk bertemu dengan masyarakat, berbincang dengan banyak orang, mampir ke rumah penduduk lokal untuk melihat proses memasak sejak awal, dan mengikuti tata cara mereka menikmatinya.'

Bermacam-macam peran makanan yang terdapat dalam masyarakat, tidak hanya sebagai pemenuh kebutuhan pokok semata melainkan kini telah memiliki peran yang lebih banyak.

\section{Hasil dan Pembahasan}

Ringkasan Cerita

Aruna dan Lidahnya merupakan sebuah novel karangan seorang penulis perempuan muda kelahiran Jakarta bernama Laksmi Pamuntjak. Novel yang

\footnotetext{
${ }^{7}$ Agoeng Wijaya, Kurniawan, Mustafa Silalahi, dkk. Edisi Khusus Tempo (Antropologi Kuliner), (Jakarta: PT Tempo Inti Media Tbk, 2014), h. 31.

${ }^{8}$ Agoeng Wijaya, Kurniawan, Mustafa Silalahi, dkk. Edisi Khusus Tempo (Antropologi Kuliner) ...., h. 48.

${ }^{9}$ Agoeng Wijaya, Kurniawan, Mustafa Silalahi, dkk. Edisi Khusus Tempo (Antropologi Kuliner) ....., h. 49.
} 
diterbitkan pada bulan November 2014 ini mengisahkan tentang tiga orang sahabat yang memiliki profesi berbeda, namun memiliki obsesi yang sama , yakni terhadap makanan. Novel Aruna dan Lidahnya dikisahkan oleh seorang gadis yang juga merupakan tokoh utama yakni Aruna Rai.

Aruna Rai, wanita 35 tahun ini penggemar kuliner dan salah satu pekerja dari konsultan yang bergerak dalam penelitian yang berhubungan dengan unggas bernama One World. Ia ditugasi meneliti berbagai kronologis terjadinya penularan flu unggas kepada sebagian penduduk Indonesia.

Perjalanan berkeliling Nusantara dari Aceh hingga Lombok ini menjadi semacam wisata kuliner bagi Aruna dan kedua sahabatnya serta rekan kerjanya, Bono dan Nadezdha, serta Farish. Bono, seorang chef profesional yang telah menempuh pengalaman sampai New York dan mampu mengolah bakmi dengan foie gras, serta Nadezdha Azhari, wanita cantik 33 tahun blasteran Sunda-Aceh-Perancis dan Persia; seorang konsultan gaya hidup yang sangat memesona sehingga menurut Aruna bila dibandingkan dengan dirinya bagaikan 'sampanye dan popcorn'. Terakhir, Farish, rekan sejawatnya dari kantor yang ditugaskan bepergian dalam menyelidiki wabah flu burung yang diketahui pada akhirnya memiliki kisah tersendiri dengan Aruna. Aruna, Nadezdha, dan Bono, ketiganya memiliki kesamaan yakni terobsesi pada makanan. Berawal dari kesamaan itulah, kisah perjalanan kuliner berkeliling hampir ke sebagian Indonesia bermulai.

Berbagai daerah yakni delapan kota, Bangkalan, Pamekasan, Palembang, Medan, Banda Aceh, Pontianak, Singkawang, Lombok, dan Mataram didatangi guna menyelediki kasus flu unggas yang merebak. Banyak kejanggalan yang ditemukan yang tidak lain ialah "permainan" oknum pejabat dalam rangka korupsi. Tidak hanya berkutat pada masalah flu unggas yang sedikit menyita pikiran Aruna dan rekan-rekannya, mereka menjadikan perjalanan ini sebagai ajang mencicipi berbagai kuliner yang terdapat di daerah itu.

Sebagai contoh, selama di Surabaya, Aruna, Bono dan Farish menikmati aneka rujak, seperti rujak cingur, rujak tolet yang memakai bumbu gula merah, kecap dan bawang putih, serta rujak deham yang berbumbu asin dengan komposisi irisan buah dan taoge. Ada juga rujak cemplung, rujak buah yang disajikan dengan kuah air kelapa. Tak lupa Rujak soto dan Botok Pakis yang menjadi pusat perhatian mereka karena komposisinya yang tak biasa. Sedangkan ketika di Kalimantan, mereka mencoba makanan khas daerah itu, seperti Kwetiaw, Rujak buah yang khas dan Sotong Pangkong. Di sana, cinta Aruna 
dan Farish mulai bersemi. Sedangkan Bono harus menanggung kekecewaan karena ditolak Nadezhda.

Ketika mendengar kabar bahwa adanya konspirasi terkait kepentingan segelintir orang dengan politik di One World, mereka semakin tidak bersemangat menjalankan tugasnya, namun pekerjaan menuntut diselesaikan. Dengan segera setelah menyelesaikan urusan, mereka kembali ke Jakarta. Ternyata di Jakarta, Aruna merindukan Lombok untuk berlibur, ketiga temannya tidak luput untuk turut serta. Misi mencicipi segala jenis kuliner tetap dijalankan. Dari sinilah kisah percintaan Aruna dan Farish berlanjut, hingga pada akhirnya Aruna memutuskan untuk hidup bersama dengan Farish.

\section{Analisis Intrinsik}

1. Tema

Tema merupakan suatu unsur yang sangat penting dalam karya sastra, tema juga merupakan ide yang mendasari suatu cerita. Pengarang biasanya menyampaikan pokok pembicaraan pada sebuah karya melalui tema. Tema yang terdapat dalam novel Aruna dan Lidahnya karya Laksmi Pamuntjak adalah mengenai kuliner (makanan). Kuliner digunakan Laksmi sebagai media untuk membangun karakter tokoh, misalnya ketika suasana tegang, makanan menjadi perantara untuk mencairkan suasana, makanan bisa menjadi perantara untuk mengetahui karakter tokoh seperti Bono yang memiliki kemauan kuat berkunjung dari satu restoran ke restoran lainnya demi obsesinya terhadap makanan. Laksmi juga menyatakan bahwa ia sudah lama ingin menulis novel dengan fokus makanan di dalamnya, meski sebelumnya ia telah menulis empat edisi resensi kuliner dengan judul The Jakarta Good Food Guide.

\section{Tokoh dan Penokohan}

Tokoh merupakan pelaku yang mengemban peristiwa dalam cerita sehingga peristiwa itu menjalin suatu cerita sedangkan cara sastrawan menggambarkan tokoh disebut penokohan. Dalam novel Aruna dan Lidahnya tokoh utamanya adalah Aruna. Aruna juga berperan sebagai pencerita dalam novel, ia digambarkan sebagai seorang yang hobi makan. Aruna juga pemalu dan pendiam, tetapi ketika berhubungan soal makanan ia akan bersuara lantang. Selain Aruna, ada dua tokoh lainnya yang digambarkan tidak kalah pentingnya, yakni Nadezhda dan Bono. Mereka berdua merupakan sahabat dekat Aruna yang juga memiliki obsesi terhadap makanan. Nadezhda digambarkan sebagai 
seorang perempuan dengan paras cantik. Ia memiliki profesi sebagai penulis di salah satu majalah yang terfokus pada makanan dan perjalanan. Selain dua tokoh tersebut, tokoh terakhir yang juga mendukung terjalinnya jalan cerita yakni Bono. Bono memiliki nama lengkap Johanes Bonafide Natalegawa merupakan chef muda berbakat dengan banyak pengalaman di dunia kuliner internasional. Ia merupakan sahabat dekat Aruna, yang jika telah bertemu, maka keduanya akan membicarakan makanan dari awal hingga akhir. Ketiga tokoh digambarkan oleh Laksmi dengan apik. Ia membuat ketiga tokoh dalam cerita saling berkaitan satu sama lain untuk membangun cerita.

\section{Alur}

Alur merupakan rangkaian peristiwa dalam sebuah cerita. Alur yang digunakan dalam novel Aruna dan Lidahnya ialah alur maju. Cerita ini dimulai dari terkuaknya kasus flu unggas yang melanda delapan kota yang kemudian Aruna dan timnya ditugaskan untuk menyeledikinya. Di sela-sela menyelesaikan tugasnya, Aruna mengajak kedua temannya untuk berwisata kuliner. Alhasil jadilah mereka mencicipi berbagai makanan di kota-kota yang didatangi. Hingga penyelidikan yang dilakukan diberhentikan sementara dan Aruna memfokuskan tujuannya untuk berwisata kuliner sepenuhnya.

\section{Latar}

Latar merupakan salah satu unsur yang menunjang terjadinya suatu cerita. Latar ialah tempat umum, waktu kesejarahan, dan kebiasaan masyarakat. Latar tempat merupakan lingkungan tempat peristiwa terjadi, latar waktu ialah waktu kapan terjadinya peristiwa, latar sosial juga pada umumnya menggambarkan keadaan masyarakat, kelompok sosial dan sikap, kebiasaan, cara hidup dan bahasanya. Dalam novel Aruna dan Lidahnya latar tempat yang digambarkan pengarang cukup banyak, karena dikisahkan tokoh utama bersama temantemannya berkeliling Indonesia untuk melakukan penyelidikan kasus flu unggas. Latar termpat yang terdapat dalam novel Aruna dan Lidahnya adalah Surabaya, Bangkalan, Sampang, Pamekasan, Palembang, Medan, Prapat, Singkawang, Pontianak, dan Lombok.

Latar waktu ialah latar yang menggambarkan kapan peristiwa itu terjadi. Dalam novel Aruna dan Lidahnya latar waktu yang disebutkan tidaklah banyak, yakni pada akhir 2012 cerita dimulai. Diawali dengan diperkenalkannya tokoh utama Aruna yang berprofesi sebagai ahli wabah yang ditugaskan untuk 
menyelidiki kasus flu unggas yang merebak di beberapa wilayah di Indonesia. Pada akhir 2012, di Indonesia sedang marak kasus flu unggas. Ditemukannya varian virus baru menambah korban yang berjatuhan semakin banyak. Selain akhir 2012, terdapat juga latar waktu lainnya yakni pada awal 2014. Awal tahun 2014 ini, kehidupan Aruna sangat mengalami perubahan, tidak hanya dari soal pekerjaan, tetapi juga mengenai masalah percintaannya dengan Farish. Ia memutuskan untuk hidup bersama.

Latar sosial pada umumnya mencakup tentang keadaan masyarakat, kelompok sosial dan sikap, adat kebiasaan, cara hidup, dan bahasa. Dalam novel Aruna dan Lidahnya latar sosial ditemukan pada status sosial yang terjadi di dalam novel yakni golongan kelas menengah ke atas, hal tersebut dilukiskan pengarang melalui perilaku tokoh-tokohnya yang kerap bergaya hidup mewah.

\section{Sudut Pandang}

Sudut pandang adalah tempat pengarang memandang ceritanya. Dari tempat itulah pengarang bercerita tentang tokoh, peristiwa, tempat, dan waktu dengan gayanya sendiri. Sudut pandang yang digunakan dalam novel Aruna dan Lidahnya ialah sudut pandang persona pertama, "Aku" tokoh utama. Narator memiliki kemampuan yang terbatas dalam mengisahkan cerita, ia hanya mahatau bagi dirinya sendiri dan tidak terhadap orang-orang atau tokoh lain dalam cerita.

\section{Analisis Obsesi Terhadap Makanan dalam Novel Aruna dan Lidahnya}

Obsesi merupakan ide, pikiran, bayangan atau emosi yang tidak terkendali, sering datang tanpa dikehendaki atau mendesak masuk dalam pikiran seseorang yang mengakibatkan rasa tertekan dan cemas. Obsesi terhadap makanan yang terdapat dalam novel Aruna dan Lidahnya difokuskan terhadap tokoh-tokoh yang berpengaruh dalam jalannya cerita, selain itu juga penulis melihat dari pemaparan Laksmi yang mengatakan bahwa ketiga tokoh ini memiliki obsesi yang sama terhadap makanan. Tokoh-tokoh tersebut adalah Aruna, Nadezhda, dan Bono.

\section{Aruna}

Aruna seorang perempuan 35 tahun, berprofesi sebagai ahli wabah dengan spesialisasi flu unggas ini masih hidup menyendiri. Ia terobsesi pada makanan. Bagi Aruna, makanan tidak hanya sebagai penghilang rasa lapar, namun makanan memiliki dunia tersendiri dalam hidupnya. Obsesi terhadap makanan 
yang terjadi pada Aruna juga disebabkan oleh beberapa faktor dalam kehidupannya. Faktor tersebut antara lain sebagai berikut.

a. Status yang Masih Sendiri (Single)

Status Aruna yang masih menyendiri, menyebabkan dirinya hanya terfokus pada dua hal dalam hidupnya, yakni makanan dan pekerjaannya. Kedua hal yang menjadi fokus dalam hidupnya itu pun masih dipisahkan olehnya dengan perumpamaan yang sangat berbeda. Hal demikian terlihat dalam kutipan di bawah ini.

“Tapi sebelum aku bercerita tentang dua kehidupanku yang bak bumi dan langit_makanan dan politik unggas_ perlu kujelaskan bahwa aku sehari hari bekerja sebagai konsultan epidemologi".

Dari kutipan di atas terlihat jelas bahwa Aruna menyatakan memiliki dua kehidupan yang berbeda dan sangat kontras. Pada satu sisi ia harus serius dalam menjalani tugasnya sebagai ahli wabah, dan pada sisi lain ia bisa menggunakan makanan sebagai ajang hiburan selepas bekerja atau di sela-sela pekerjaannya. Oleh karena itu, kesendirian yang dialami oleh Aruna membuatnya terfokus pada suatu hal yang membuatnya senang, hal tersebut tidak lain adalah makanan.

b. Sarana Pembebasan Diri

Salah satu pemicu terjadinya obsesi ialah stres, ketika stres melanda, Aruna menggunakan makanan sebagai ajang pembebasan diri. Ia melampiaskan semuanya kepada makanan.

"Dan begitulah, dalam sekejap aku kembali tersingkirkan. Aku, Aruna yang di mata mereka hanyalah si konsultan aneh, si manusia burung, nerd. Tapi aku tak peduli, karena saat itu telah kubebaskan diriku untuk menyerap bau dan bumbu. Pelan-pelan kusurup lagi telunjuk yang baru saja kucelupkan ke dalam kuah kol nenek. Pedas, amis, sedikit manis".

Kutipan tersebut menggambarkan ketika Aruna merasa mengalami tekanan dalam dirinya, meski tidak besar, ia kembali melampiaskannya pada makanan. Ia membebaskan diri untuk berfokus hanya kepada makanan yang saat itu berada di hadapannya. Ketika seseorang merasa stres, makanan memang bisa menjadi salah satu obatnya. Seperti beberapa makanan yang bisa membuat

\footnotetext{
${ }^{10}$ Laksmi Pamuntjak. Aruna dan Lidahnya, (Jakarta: PT Gramedia Pustaka Utama, 2014), h. 21.

${ }^{11}$ Laksmi Pamuntjak. Aruna dan Lidahnya ....., h.34-35
} 
lebih rileks dan mengurangi tingkat stres atau depresi ketika kita mengkonsumsinya, yaitu kacang kenari, cokelat, buah-buahan dan ikan. ${ }^{12}$

c. Sumber Kebahagiaan

Selain sebagai penghilang rasa lapar dan sebagai sarana pembebasan diri, ternyata makanan memiliki fungsi lain bagi Aruna. Makanan merupakan salah satu sumber kebahagiaan. Hal demikian tampak seperti kutipan di bawah ini.

"Aruna, telah lama memutuskan bahwa ia akan menyediakan waktunya hanya untuk hal-hal yang membuatnya bahagia, dan ini sangat masuk akal karena orang yang tidak banyak bicara sering disalahartikan sebagai orang yang tidak bahagia, dan dalam usianya sekarang, dianggap tidak bahagia bukanlah sesuatu yang menyenangkan, malah sedikit menyebalkan menjurus ke tidak adil, karena yang tersirat adalah sebentuk kepribadian yang lemah, sepotong jiwa yang rentan, padahal ia seratus delapan puluh derajat berbeda, paling tidak begitulah ia melihat dirinya sendiri, sebab bagaimana mungkin ia tak berkepribadian apabila satu-satunya hal yang membuatnya bahagia adalah makanan,...".

Berdasarkan kutipan di atas, salah satu hal yang membuat Aruna bahagia ialah makanan, oleh karena itu tidak heran jika ia begitu menggemari makanan hingga terobsesi. Seperti dinyatakan dalam kutipan tersebut, Aruna hanya menyediakan waktu untuk hal-hal yang membuatnya bahagia, salah satunya ialah makanan. Makanan memang bisa mengubah sesuatu, dari suasana yang dingin dan kaku misalnya seketika bisa mencair berkat adanya pembicaraan di meja makan.

Berdasarkan pemaparan di aras, obsesi yang dialami Aruna disebabkan oleh beberapa faktor yakni statusnya yang masih sendiri, sebagai sarana pembebasan diri, serta sebagai sumber kebahagiaan. Hingga akhir cerita, Aruna tetap tidak bisa lepas dari makanan. Setelah memutuskan untuk hidup bersama Farish dan keluar dari pekerjaannya yang semula, ia menanam saham di Siria 2, yakni cabang restoran yang dimiliki oleh Bono. Ia juga bereksperimen mengenai makanan bersama Bono berdasarkan perjalanan yang telah mereka lakukan.

\footnotetext{
${ }^{12}$ Unoviana Kartika. Makanan Yang Bantu Atasi Stres dan Cemas. Artikel diakses pada 9 September 2015 dari http:/ / health.kompas.com/read/Makanan.yang.Bantu.Atasi.Stres.dan.Cemas.

${ }^{13}$ Laksmi Pamuntjak. Aruna dan Lidahnya ....., h. 12.
} 


\section{Nadezhda}

Nadezhda yang memiliki nama lengkap Nadezhda Azhari merupakan salah satu sahabat Aruna dengan obsesi yang sama, yakni makanan. Terkadang obsesi ini membuatnya tertekan dan stres karena ia mengkhawatirkan dirinya sendiri sebagai penulis dengan spesialisasi makanan yang dianggap dangkal oleh pembaca.

"Coba, bagaimana menurul lu gue diniai sesama penulis? Oh itu dia si Nadezhda, penulis makanan dan gaya hidup itu. Penulis ecek-ecek. Second-rate write.". ${ }^{14}$

Berdasarkan kutipan di atas, Nadezhda yang terobsesi dengan makanan bisa mengalami stres karena mengkhawatirkan anggapan pembaca soal dirinya yang terus-menerus memikirkan makanan. Sama halnya dengan Aruna, obsesi terhadap makanan yang dialami Nadezhda memiliki beberapa faktor, di antaranya.

a. Pekerjaan

Memiliki pekerjaan sebagai seorang penulis dengan spesialisasi makanan dan perjalanan mengharuskannya mengenal berbagai jenis makanan untuk diulas. Hal tersebut tampak pada kutipan di bawah ini.

"Dua, lu punya pikiran lu sendiri tentang makanan. Orang banyak belajar dari lu. Soalnya lu bukan cuma lapor makan di sana sini, lu selalu mencoba menelaah lebih, mengaitkan apa yang lu makan dengan hal-hal lain”."

Kutipan di atas menjelaskan bahwa Nadezhda memang akrab dengan makanan, pekerjaannya yang setiap hari mengharuskan dirinya bersentuhan langsung dengan makanan membuatnya terobsesi dengan makanan

\section{b. Gaya Hidup}

Besar dalam lingkungan yang mewah membuat Nadezhda sangat memperhatikan gaya hidup. Cara berpakaian, tampil di depan banyak orang, serta bagaimana gaya dalam berbicara. Semua hal itu membuat Aruna iri terhadapnya, namun mereka tetap bersahabat. Nadezhda yang merupakan keturunan Aceh-Sunda-Prancis selalu tampil menawan dan selalu mementingkan gaya hidup. Hal tersebut tampak pada kutipan di bawah ini.

\footnotetext{
${ }^{14}$ Laksmi Pamuntjak. Aruna dan Lidahnya ....., h.84.

15 Laksmi Pamuntjak. Aruna dan Lidahnya ....., h.86.
} 
"Aku segera duduk di sebelahnya. Ini jam tiga sore hari Sabtu, jam tidur siang, tapi restoran masih penuh sesak oleh manusia-manusia indah yang bersikukuh, sampai menit penghabisan, menghabiskan waktu dan duit demi secuil gaya hidup. Juga anggota brigade pekerja lepas seperti Nadezhda yang bersikukuh gaya hidup adalah pekerjaan, dan pekerjaan adalah gaya hidup".

Berdasarkan kutipan di atas, Nadezhda menganggap pekerjaannya sebagai gaya hidup, dan gaya hidupnya sebagai pekerjaannya. Hal ini membuktikan bahwa pekerjaan yang dijalaninya sekarang sebagai penulis dengan spesialisasi makanan dan perjalanan merupakan sebuah gaya hidup.

c. Teman

Faktor yang ketiga ialah teman. Lingkungan sangat berpengaruh membentuk sikap dan perilaku seseorang, meski keluarga juga memegang peranan penting. Nadezhda yang bergaul dengan sahabat-sahabatnya yang penggemar makanan juga, merasakan kecocokan. Aruna dan Bono, dua orang yang juga terobsesi pada makanan. Mereka kerap melakukan perjalanan hanya demi tujuan kuliner. Terlebih Nadezhda ketika bertemu dengan Bono, mereka cocok dalam membicarakan mengenai makanan. Bono yang berprofesi sebagai seorang chef selalu memperhatikan tren makanan demi kemajuan restorannya. Jadilah ketika bertemu, topik yang dibahas tidak lain adalah makanan.

Berdasarkan pemaparan di atas, obsesi yang dimiliki oleh Nadezhda tidak hanya didukung oleh gaya hidupnya yang mewah dan pekerjaan, akan tetapi faktor pertemanan juga berpengaruh terhadap dirinya. Hingga akhir cerita, Nadezhda dan Aruna masih tetap kerap makan bersama seminggu sekali. Makanan memang selalu akrab dengan mereka berdua.

\section{Bono}

Sahabat Aruna yang berprofesi sebagai chef ini juga memiliki obsesi yang sama dengan Nadezhdan dan Aruna, yakni makanan. Pertemuannya dengan Aruna terjadi pertama kali ketika mereka bekerja sama pada sebuah proyek yang sama, Aruna bekerja di lembaga advokasi dan Bono bekerja di perusahaan PR. Bono dan Aruna ternyata memiliki kesamaan dalam selera makan. Berawal dari kerja pada proyek yang sama dan hobi yang sama terhadap makanan, mereka akhirnya bersahabat baik. Obsesi terhadap makanan yang dialami oleh Bono juga disebabkan oleh beberapa faktor, diantaranya sebagai berikut.

${ }^{16}$ Laksmi Pamuntjak. Aruna dan Lidahnya ....., h.81. 
a. Pekerjaan

Bono, yang berprofesi sebagai chef di salah satu restoran terkenal di Jakarta ini kerap mendatangi satu restoran ke restoran lainnya demi mengasah indera perasanya. Kecintaannya terhadap makanan tidak lain disebabkan karena pekerjaannya yang setiap hari bersentuhan langsung dengan makanan.

"Tapi aku tahu jawabannya: ia jarang salah karena ia pengunjung restoran yang tak kenal lelah. Insting hanya datang dari pengalaman; ia tak jatuh dari langit, atau menyelusup seperti jin ke dalam tubuh, yang dengan baik hatinya mengarahkan panca indramu untuk membuat pilihan-pilihan paling jitu". ${ }^{7}$

Berdasarkan kutipan di atas, Bono kerap mengunjungi satu restoran ke restoran lainnya demi ketajaman indra perasanya yang ketika memilih makanan, ia jarang salah. Profesinya sebagai chef menuntut Bono untuk selalu menciptakan inovasi baru dalam masakannya.

b. Latar Belakang Pendidikan

Dalam rangka mewujudkan mimpinya, Bono menempuh pendidikan ke luar negeri. Berbagai jabatan pekerjaan pun pernah dilakoni oleh Bono sebelum akhirnya ia menjadi seorang chef profesional. Obsesinya terhadap makanan juga disebabkan oleh latar belakang pendidikannya, karena bergaul dan bersosialisasi dengan para chef yang senior membuat Bono kerap harus memiliki banyak keterampilan, ia berusaha keras untuk itu, dan pada akhirnya ketika kembali ke Jakarta, ia telah mencapai mimpinya.

"Ia tahu bagaimana bicara tentang tren makanan terkini, dari gastronomi molekuler, raw food, dan eksperimen dengan wine sampai filsafat makanan yang dekat dengan tanah dan laut" ${ }^{18}$

Berdasarkan kutipan di atas, seseorang yang memiliki keterampilan memukau tidaklah hadir begitu saja, namun memerlukan latihan dan pengalaman yang banyak. Bono telah melewati itu semua, mencoba akrab dengan berbagai jenis makanan. Berdasarkan pemaparan tersebut, obsesi yang dialami oleh Bono disebabkan oleh beberapa faktor, di antaranya ialah pekerjaan dan latar belakang pendidikan. Selain itu di akhir cerita Bono kembali membuka cabang untuk restorannya, Siria 2. Ia juga diketahui menjalin hubungan dengan seorang wanita yang kabarnya sesama foodie.

\footnotetext{
${ }^{17}$ Laksmi Pamuntjak. Aruna dan Lidahnya ....., h.42.

${ }^{18}$ Laksmi Pamuntjak. Aruna dan Lidahnya ....., h.34-35h.47.
} 


\section{Simpulan}

Berdasarkan hasil penelitian yang telah dilakukan terhadap novel Aruna dan Lidahnya karya Laksmi Pamuntjak, maka dapat disimpulkan bahwa obsesi terhadap makanan yang dialami oleh tokoh-tokoh yang ada dalam novel disebabkan oleh beberapa faktor di antaranya sebagai berikut. Tokoh utama yakni Aruna, terobsesi terhadap makanan karena beberapa faktor. Faktor pertama yakni kehidupannya yang masih sendiri (single). Kesendirian menyebabkan Aruna hanya terfokus pada makanan. Kedua, makanan sebagai sarana pembebasan diri. Ketika Aruna mengalami stres, makanan digunakan sebagai ajang pembebasan diri. Ketiga, makanan sebagai sumber kebahagiaan. Makanan menjadi salah satu sumber kebahagiaan bagi Aruna, oleh karena itu ia menjadi terobsesi terhadap makanan. Hingga akhir cerita, Aruna tetap tidak bisa lepas dari makanan. Setelah memutuskan untuk hidup bersama Farish dan keluar dari pekerjaannya yang semula, ia menanam saham di Siria 2, yakni cabang restoran yang dimiliki oleh Bono. Ia juga bereksperimen mengenai makanan bersama Bono berdasarkan perjalanan yang telah mereka lakukan.

Tokoh kedua yakni Nadezhda. Obsesinya terhadap makanan juga disebabkan oleh beberapa faktor. Pertama, Nadezhda terobsesi dengan makanan karena pekerjaannya. Pekerjaannya sebagai penulis dengan spesialisasi makanan dan perjalanan membuatnya selalu bersinggungan dan akrab dengan makanan. Kedua, gaya hidup. Nadezhda sangat mementingkan gaya hidup, hal itu dibuktikan dengan berkunjung dari satu restoran ke restoran lainnya. Faktor ketiga ialah teman. Bono, sebagai teman Nadezhda sangat mempengaruhi obsesinya terhadap makanan. Hingga akhir cerita, Nadezhda dan Aruna masih tetap kerap makan bersama seminggu sekali. Makanan memang selalu akrab dengan mereka berdua.

Tokoh ketiga ialah Bono. Ia terobsesi dengan makanan karena faktor pekerjaan dan latar belakang pendidikan. Selain itu, di akhir cerita Bono kembali membuka cabang untuk restorannya, Siria 2. Ia juga diketahui menjalin hubungan dengan seorang wanita yang kabarnya sesama foodie. Tokoh keempat ialah Farish yang tidak memiliki obsesi terhadap makanan dan kurang menyukai makan di luar, namun tertular menjadi gemar makan oleh Aruna dan temantemannya, hingga pada akhirnya Farish memutuskan untuk hidup bersama dengan Aruna. 


\section{Daftar Pustaka}

Anggraeni, Mareta. Perilaku Obsesif Kompulsif Disorder pada Peserta Penurunan Berat Badan. Skripsi Universitas Brawijaya Malang: Tidak diterbitkan. 2013.

Arjadi, Retha. Melakukan Sesuatu Berulang, Waspadai Gangguan ObsesifKompulsif. Jakarta: PT. Kompas Media Nusantara. 2015.

Kartika, Unoviana. Makanan Yang Bantu Atasi Stres dan Cemas. Artikel diakses pada 9 September 2015 dari http://health.kompas.com/Makanan.yang.Bantu.Atasi.Stres.dan.Cemas.

Nurgiantoro, Burhan. Teori Pengkajian Fiksi. Yogyakarta: Gajah Mada University Press. 2010.

Pamuntjak, Laksmi. Aruna dan Lidahnya. Jakarta: PT Gramedia Pustaka Utama, 2014.

Wijaya, Agoeng Kurniawan, Mustafa Silalahi, dkk. Edisi Khusus Tempo (Antropologi Kuliner). Jakarta: PT Tempo Inti Media Tbk, 2014

Wright, Robin Redmon. You are What You Eat!? Television Cooking Show, Consumotion, and Lifestyle Practices as Adult Learning. San Antonio: New Prairie Press, 2009.

Zaidan, Abdul Rozak, Anita K.Rustapa dkk. Kamus Istilah Sastra. Jakarta: Balai Pustaka. 2007. 